\title{
DIFFERENCES IN SPATIAL ORIENTATION IN CHILDREN WITH AND WITHOUT VISUAL IMPAIRMENT WITH REGARD TO AGE, GENDER AND SCHOOL ACHIEVEMENT
}

\author{
Ševala Tulumović ${ }^{1}$ \\ Dragica Omerćehajić \\ Izeta Husić-Đuzić
}

Original scientific paper

Faculty of Education and Rehabilitation, University of Tuzla, Bosnia and Herzegovina

Received: $2018 / 11 / 5$

Accepted: 2019/2/2

\begin{abstract}
The aim of the research is to examine the differences in the spatial orientation of children with and without visual impairment with regard to age, gender, and school achievement. The sample of respondents consisted of a total of 62 respondents, of whom: 31 respondents with visual impairment and 31 respondents without visual impairment, aged 7-11, both sexes obtained from the pupil population from the first to the eighth grade of regular primary schools in the Tuzla Canton area. The obtained results were processed by descriptive analysis, $t$-test and variance analysis. By analyzing the results on variables for the estimation of spatial orientation, we can conclude that the two investigated groups statistically significantly differ in spatial orientation with regard to: age, while the differences were not shown on the variables: gender, and school achievement. The results of the research can be used to create new methods for implementing and improving the rehabilitation process in this population of children. Rehabilitation with children with visual impairment can positively influence the reduction of the differences in the spatial orientation of this population in relation to children of intact vision, and on the educational process, social and professional integration of this population.
\end{abstract}

Keywords: spatial orientation, children with visual impairment, children without visual impairment

\section{INTRODUCTION}

The sense of vision (eyesight) is a complex organ by which the human establishes the most important and most perfect sensory connections with the environment (Smiljanić, 2001). The eyesight is one of the senses with which we notice, we discern the light, colors, shapes, distances and spatial relationships (Stefanović, 1996). The eyesight allows identification of objects, events, people, much more successful than other sensory-perceptual channels (Warren, 1981). Visual impairment is a major and growing health and socioeconomic problem (Courtright et al., 2011). The frequency of visual impairment caused by genetic and incurable neurophthalmic diseases is on the rise, such a complex etiology of visual impairment often causes multiple difficulties in children (Boonstra et al., 2012).

\footnotetext{
Correspondence to:

Ševala Tulumović, PhD, Faculty of Education and Rehabilitation, University of Tuzla, Bosnia and Herzegovina

Univerzitetska 1, 75000 Tuzla, Bosnia and Herzegovina

Phone:+38735320673

E-mail: sevala.tulumovic@untz.ba
} 
Perception is structured by the laws of the perceptual organization (Wertheimer, 1999). The space is perceived by the integrative cooperation of all senses. Space is the environment in which we find what we perceive, one from one another (Marić, 1991). In this same space we perceive that objects are localized in different places, we hear where they are and we touch them in different places of space (Crutch \& Crutchfield, 1980). Visual information has the most important integrative function in linking information from various perceptual modes (visual, audible, tactile) to one whole in the perception of space (Ognjenović, 1992). The process of object perception distinguishes three stages: object discrimination, object recognition and identification. The perception of the third dimension of objects is very complex and involves binocular vision, eye movements and cognitive information processing. It is important to keep in mind that the perception of a particular object is more than something that has a certain size, shape, color, movement. It should be noted that visual attributes have a dominant role in the perception of objects, but most often in the integration with information from other senses (Eškirović, 2002). The perception of the space of visually impaired children has a strong influence on the constellation factors: the illumination of the perceived spaces and the exclusion of the object space. Saturation and other dimensions of colors in perceived objects in space and size of objects, etc., also play a significant role. Of the internal factors for perception of space, the most important are the physiological factors: the type of visual impairment, visual acuity, the width of the visual field, the quality of stereoscopic vision. The monocular perceptions of the depth space are several times slower than the binocular perceptions. The lack of visual control of these situations leads to difficulty in adopting their meaning in children with visual impairment (Tulumović \& Husić, 2017). The biggest problem in space perception is the perception of the third dimension-depth, as well as the ability of spatial analysis and synthesis. Educational abilities of children with impaired vision are largely based on the quality of visual perception of space (Tulumović et al., 2013). These children have a lot of difficulty in perceiving perspectives, orientation in space and stability in the perception of space. Partially sighted children with usable vision on both eyes, but with certain deviations in binocular vision, will have significant difficulties in space perception. Particularly expressed are the difficulties of partially sighted children whose visual impairment as a cause of amblyopia (partial sight) is accompanied by srabism. According to Zemcova, on the sample of the visually impaired children and children of intact vision in the fixation of the view, the assessment of the depth of the area, the monitoring of moving objects, the disturbances in the motor mobility of their eyes will be directly reflected in spatial analysis and synthesis. In the experimental study (Filin, 1987, according to Eškirović, 2002), on the sample of visually impaired children and children of intact vision it was found that all the visually impaired children showed significant deviations regarding the fixation of a bright or imagined point in the space. It is very important, in addition, to determine at what distance the partially sighted student specifically perceives the movements of teachers and students in the classroom. Characteristics are conditioned by reduced visual capabilities, which make it difficult for them to get to know the outside world. In the formation of teaching with children with visual impairment, the key role is to learn about their cognitive, perceptual and motor abilities (Tulumović, 2013). Partially sighted children for the perception of the environment, other than the remaining senses, also use the rest of the sight, but they also need more time. On the other hand, the concept of the need for organizing teaching activities that will enable these children to make the most efficient use and minimum capacities of the visual system is based on examples from corrective teaching and the results of various researches (Tulumović et al., 2012). Partially sighted children show significant deviations in discrimination of the basic characteristics of perceived objects and model objects in a classroom and in another environment. In the previous research, the greatest difficulty is registered in terms of the form and structure of the object. An increasing number of partially sighted students exhibit certain difficulties in naming the most elementary objects of everyday life. It is very important to determine what is the ability of partially sighted children to identify the model of an object that is familiar to them in their natural form. Failure to solve these tasks can be the result of: inability to notice any difference, misunderstanding of terms of similarity and discrimination, failure in the percentage of searches and observations. Significant information on the peculiarities of the visual observation of the partially sighted children in the teaching can be obtained on the basis of how to solve tasks and matching identical models in a series of objects (Eškirović, 2002, according to Omerćehajić, 2017). 


\section{AIM OF THE WORK}

To determine the differences in the spatial orientation of children with and without visual impairment with regard to age, gender, and school achievement.

\section{METHODS}

\section{Sample respondents}

The sample of respondents consisted of children with visual impairment, elementary school age and children of intact vision, who, by age and gender, were equated with an experimental group. The survey covered a total of 62 respondents: 31 visually impaired respondents, 31 respondents without visual impairment, aged 7-11, both genders. Children with visual impairment who are integrated in regular schools in the Tuzla Canton area and children of intact vision who attend regular school in the Tuzla Canton area. The selection criteria were: children with visual impairment, without intellectual disabilities, both genders, aged 7 to 11 .

\section{Measuring instruments and method of conducting} research

The research was conducted in regular elementary schools in the Tuzla Canton. Preliminary preparations were made in schools, which consisted of detailing the way in which the examination was conducted to students. The parents of children with visual impairment, as well as parents of children without visual impairment, school directors and teaching staff, were introduced to the method of examination. The test was conducted individually. In the study of spatial orientation in children with visual impairment, a "Diagnostic kit for testing the ability of speech, language, reading and writing in children" was used (Bjelica \& Posokhova, 2001).

\section{Data processing methods}

Data processing was carried out using the SPSS 17.0 for Windows software package. In addition to calculating the descriptive-statistical parameters, the measure of central tendency and variability, the test of the difference (equity) of the arithmetic meanings of two or more basic sets was used as a parameter test. To test the existence of a difference in mean values between groups of respondents formed by age (independent samples), as well as other criteria, a p-value was used. As nonparametric tests, chi-squared test and t-test for the significance of differences in the arithmetic mean of variables, variance analysis was used. The survey was conducted with a level of significance of $5 \%(.05)$.

\section{RESULTS}

In order to determine the differences in relation to the obtained results of spatial orientation in children with and without visual impairment in relation to gender, a ttest was applied. Based on the results obtained in Table 1 , it can be seen that male respondents achieve better results on variables "Spatial Orientation", "Reproducing Directions," "Reproduction of Spatial Orientation and Spatial Practices", and "Ability to Verbal Motion Control", while female respondents achieve better results on the variable "Ability to adopt concepts". Although differences in the achieved results have been established, they are not statistically significant.

Table 1. Analysis of t-test results in spatial orientation among children with and without visual impairment with regard to gender

\begin{tabular}{|c|c|c|c|c|c|}
\hline Variables & Gender & $\overline{\mathbf{A M}}$ & SD & $t$ & $p$ \\
\hline \multirow{2}{*}{ Spatial Orientation } & Male & 2.00 & 0.89 & \multirow{2}{*}{1.38} & \multirow{2}{*}{.179} \\
\hline & Female & 1.53 & 0.99 & & \\
\hline \multirow{2}{*}{ Reproducing Directions } & Male & 2.81 & 0.40 & \multirow{2}{*}{1.49} & \multirow{2}{*}{.148} \\
\hline & Female & 2.47 & 0.83 & & \\
\hline \multirow{2}{*}{$\begin{array}{l}\text { Reproduction of Spatial Orientation and } \\
\text { Spatial Practices }\end{array}$} & Male & 1.69 & 0.87 & \multirow{2}{*}{.56} & \multirow{2}{*}{.581} \\
\hline & Female & 1.47 & 1.30 & & \\
\hline \multirow{2}{*}{ Ability to Adopt Concepts } & Male & 1.38 & 0.96 & \multirow{2}{*}{-.06} & \multirow{2}{*}{.950} \\
\hline & Female & 1.40 & 1.24 & & \\
\hline \multirow{2}{*}{ Ability to Verbal Motion Control } & Male & 1.69 & 1.08 & \multirow{2}{*}{.56} & \multirow{2}{*}{.581} \\
\hline & Female & 1.47 & 1.13 & & \\
\hline
\end{tabular}


Table 2 shows the results of the t-test with regard to the age of respondents with and without visual impairment. Based on the obtained t-test results, it can be concluded that there is a statistically significant difference in relation to the age of respondents and variables related to: ,, Spatial Orientation “ $(\mathrm{t}=-3,94$; $\mathrm{p}=.000)$, ,Reproducing Directions“ $(\mathrm{t}=-3,67 ; \mathrm{p}$ $=.001)$, ,Reproduction of Spatial Orientation and Spatial Practices“ ( $\mathrm{t}=-5,36 ; \mathrm{p}=.000)$,Ability to Adopt Concepts“ $(\mathrm{t}=-4,64 ; \mathrm{p}=.000)$, and ,Ability to Verbal Motion Control“" $(\mathrm{t}=-2,38 ; \mathrm{p}=.024)$. All results obtained support the respondents aged 10-11.

Table 2. Analysis of t-test results in spatial orientation among children with and without visual impairment with regard to age

\begin{tabular}{|c|c|c|c|c|c|}
\hline Variables & Age & $\mathbf{A M}$ & SD & $t$ & $\boldsymbol{P}$ \\
\hline \multirow{2}{*}{ Spatial Orientation } & 7-9 Years old & 1.20 & 1.01 & \multirow{2}{*}{-3.94} & \multirow{2}{*}{.000} \\
\hline & 10-11 Years old & 2.31 & .48 & & \\
\hline \multirow{2}{*}{ Reproducing Directions } & 7-9 Years old & 2.27 & .80 & \multirow{2}{*}{-3.67} & \multirow{2}{*}{.001} \\
\hline & 10-11 Years old & 3.00 & .00 & & \\
\hline \multirow{2}{*}{ Reproduction of Spatial Orientation and Spatial Practices } & 7-9 Years old & .80 & 1.01 & \multirow{2}{*}{-5.36} & \multirow{2}{*}{.000} \\
\hline & 10-11 Years old & 2.31 & .48 & & \\
\hline \multirow{2}{*}{ Ability to Adopt Concepts } & 7-9 Years old & .67 & .98 & \multirow{2}{*}{-4.64} & \multirow{2}{*}{.000} \\
\hline & 10-11 Years old & 2.06 & 68 & & \\
\hline \multirow{2}{*}{ Ability to Verbal Motion Control } & 7-9 Years old & 1.13 & 1.13 & \multirow{2}{*}{-2.38} & \multirow{2}{*}{.024} \\
\hline & 10-11 Years old & 2.00 & .89 & & \\
\hline
\end{tabular}

In order to determine the differences in relation to the on the obtained results of the univariate variance analysis variables of spatial orientation in children with and with- shown in Table 3, it can be concluded that there is no staout visual impairment with regard to the school achieve- tistically significant difference in relation to the variables ment, a univariate variance analysis was applied. Based of spatial orientation and school achievement.

Table 3. Analysis of the results of the F-test in spatial orientation among children with and without visual impairment with regard to school achievement

\begin{tabular}{|c|c|c|c|c|c|c|}
\hline Variable & & $\mathbf{S S}$ & df & MS & $F$ & $P$ \\
\hline \multirow{3}{*}{ Spatial Orientation } & Among & 1.31 & 2 & .65 & \multirow{3}{*}{.70} & \multirow{3}{*}{.50} \\
\hline & Within & 26.10 & 28 & \multirow[t]{2}{*}{.93} & & \\
\hline & Total & 27.41 & 30 & & & \\
\hline \multirow{3}{*}{ Reproducing Directions } & Among & .38 & 2 & .19 & \multirow{3}{*}{.42} & \multirow{3}{*}{.65} \\
\hline & Within & 12.70 & 28 & .45 & & \\
\hline & Total & 13.09 & 30 & & & \\
\hline \multirow{3}{*}{$\begin{array}{l}\text { Reproduction of Spatial } \\
\text { Orientation and Spatial } \\
\text { Practices }\end{array}$} & & .07 & 2 & .03 & \multirow{3}{*}{.02} & \multirow{3}{*}{.97} \\
\hline & Within & 35.47 & 28 & 1.26 & & \\
\hline & Total & 35.54 & 30 & & & \\
\hline \multirow{3}{*}{ Ability to Adopt Concepts } & Among & 5.64 & 2 & 2.82 & \multirow{3}{*}{2.66} & \multirow{3}{*}{.08} \\
\hline & Within & 29.70 & 28 & 1.06 & & \\
\hline & Total & 35.35 & 30 & & & \\
\hline \multirow{3}{*}{$\begin{array}{l}\text { Ability to Verbal Motion } \\
\text { Control }\end{array}$} & Among & .09 & 2 & .04 & \multirow{3}{*}{.03} & \multirow{3}{*}{.96} \\
\hline & Within & 35.45 & 28 & 1.26 & & \\
\hline & Total & 35.54 & 30 & & & \\
\hline
\end{tabular}




\section{DISCUSSION}

Partially sighted children for the perception of the environment use all their senses. In the period of mastering compensatory skills, visual perception of these children is distinguished by: sluggishness, fragmentation, unsystematicness. Highly sighted children at the beginning of schooling have more serious problems in establishing the need to extract the necessary information from the screened images on the retina. Regarding the relation between visual efficacy and visual impairment as a cause of amblyopia, it is certain that partially sighted children within certain categories of visual impairment show certain specificities in the visual perception of teaching material. Partially sighted pupils with high myopia have the need to observe objects, models, drawings from very close distances. In this way, the model can be taken as a whole or an optimal part. Partially sighted pupils with hyperopia have a lot of difficulty in perception of objects, models, images and text (Dikić, 1988). The eyesight is one of the five senses, and through which we notice, we discern the light, colors, shapes, distances and spatial relationships. Therefore, rightly it is today that man is primarily a visual being (Stefanović, 1996). The eyesight is also important for conceptual development and plays an important role in the development of the concept of an object, in the understanding that an object exists, it lasts even when it disappears from immediate observation. The eyesight enables the identification of objects, events, and people, much more successful than other sensory-perceptual channels (Warren, 1981). In the Dikić research, it was established that the visually impaired children of elementary school age of different categories of visual disturbance or visual impairment show certain specificities within the basic areas of visual perception. For high partially sighted children, visual acuities of up to 0.1 of the heaviest tasks were in the areas of visual perception, eye coordination, discrepancy between figures and backgrounds and continuity of the form. Regarding the influence of the visual field on visual efficiency of slightly sighted pupils, the data are very small, children with a wide field of vision reaching up to 5 degrees can look at items of 5 centimeters in size. Children with a field width of 5-15 degrees can cover subjects up to 15 centimeters in height at a distance of up to 33 centimeters. Partially sighted children with significantly narrowed field of vision reaching 30 or 40 degrees, on one or both eyes, have a significantly endangered binocular and stereoscopic vision. The perception of the shape and size of objects, text, and complex teaching material is difficult. Regarding the relation between visual efficacy and visual impairment as a cause of amblyopia, it is certain that partially sighted children within certain categories of visual impairment show certain specificities in the visual perception of teaching material (Eškirović, 2002). The perception of the space of partially sighted children has a great influence on constellation factors: the illumination of perceived space and the fulfillment of space by objects. Saturation and other dimensions of perceived objects in the space, the size of the object have a significant role as well. Disorders of motor mobility of their eyes will directly affect the spatial analysis and synthesis. In assessing the development of visual efficiency in object classification, it is very important to engage a partially sighted student in solving the task of allocating a model that, by certain elements, differs from the presented models with the same name in a series (Faye, 1976). Gayleenne (1990) carried out a study of the characteristic of the perception of certain observational properties of the partially sighted pupils. The study was conducted on a sample of 80 partially sighted pupils of lower grades of elementary school and 80 of their peers of intact vision. As a data collection tool, series of pairs of objects and models are distinguished by one or more observational properties: color, form, structure, and size. The results showed that both groups were very successful in discriminating and matching objects based on color and size. Differences have been shown in the discrimination and matching of objects and models within the dimensions of form and structure, the differences obtained were in both cases (Eškirović, 2002). A similar study was conducted by Gayleane (1990) with 80 partially sighted students and 80 intact vision students where the relationship between visual acuity and object classification was examined. The results showed statistically significant correlation between visual acuity and success in classifying objects based on color, size, form, and structure (Eškirović, 2002).

\section{CONCLUSION}

Based on the analysis of the obtained results of the research itself, the following conclusion can be made: Based on the research carried out and the interpretation of the obtained results on the variables for the estimation of spatial orientation, we can conclude that the two investigated groups statistically significantly differ in spatial orientation with regard to: age, while the differences were not shown on the variables: gender, and school achievement. 
Based on the results obtained, one could act preventative, by implementing an appropriate rehabilitation treatment at an appropriate age (early age, pre-school age, juvenile elementary school age, senior elementary school age). Elementary school age provides the most opportunities for permanent tiflological rehabilitation as part of regular and corrective classes.

\section{REFERENCES}

Boonstra, N., Limburg, H., Tijmes, N., van Genderen, M., Schuil, J. \& van Nispen, R. (2012). Changes in causes of low vision between 1988 and 2009 in a Dutch population of children. Acta Ophthalmol, 90, 277-86.

Bjelica, J. \& Posokhova, I. (2001). Dijagnostički komplet za ispitivanje sposobnosti govora, Jezika, čitanja i pisanja djece. Lekenik: Ostvarenje.

Courtright, P., Hutchinson, AK., \& Lewallen, S. (2011). Visual impairment in children inmiddle- and lower-income countries. Arch Dis Child, 96, 1129-34.

Ćehić, E. (1990). Specifičnosti u učenju i razvoju ličnosti djece normalna vida i slijepe djece. Beograd: Kultura.

Dikić, S. (1988). Specifičnosti vizuelnog opažanja slabovidnih učenika. Beograd, Naučna knjiga.

Dikić, S. (1997). Tiflologija. Beograd: Ideaprint.

Eškirović, B. (2002). Vizualna efkasnost slabovide dece u nastavi. Beograd: SD Publik.

Faye, E. E. (1976). Clinical Low Vision. Little Brown, Nev York.

Kreč, D. \& Kračfild, R. (1980). Elementi psihologije. Beograd: Naučna knjiga.
Marić, S. (1991). Filozofski rečnik. Beograd: Dereta.

Ognjenović, P. (1992). Psihologija opažanja. Beograd: Naučna knjiga.

Omerćehajić, D. (2017). Vizuelno perceptivne sposobnosti djece oštećenog vida u prostornoj orijentaciji $i$ verbalizaciji prostornih odnosa. Magistarski rad. Edukacijsko-rehabilitacijski fakultet Univerziteta u Tuzli.

Smiljanić, N. (2001). Ispitivanje vidnih funkcija. Beograd: Zavod za udžbenike i nastavna sredstva.

Stefanović, B. (1996). Osnovi rehabilitacije lica oštećenog vida. Beograd: Zavod za udzbenike i nastavna sredstva.

Tulumović, Š. (2013). Usmena i pismena komunikacija učenika s oštećenjem vida. Tuzla: OFF SET.

Tulumović, Š. \& Huremović, A. \& Adilović, Dž. (2013). Prostorna orijentacija djece oštećenog vida. Knjiga sažetaka sa sedmog međunarodnog Simpozija, „Umjetnost i znanost u razvoju životnog potencijala" Hrvatska: Brioni.

Tulumović, Š., Mujkić Mašić, A. \& Adilović, Dž. (2012). The differences in passive vocabulary among blind, low vision students and students without visual impairment. The Journal of International Social Research, Uluslararas1 Sosyal Ara tirmalar Dergisi, 5 (22), 211-218.

Tulumović, Š., Eškirović., B. \& Husić-Đuzić, I. (2017). Problems writing from dictation for blind and visually impaired students. HUMAN, 7 (1): 34-39.

Waren, D. H. (1981). Visual Impairments, hendbook of special education. Cllifs: Prentice-Hall, Englewood.

Wertheimer, M. (1999). Untersuchungen zur Lehre von der Gestalt, II [Laws of organization of perceptual forms]. Psycholoche Forschung, New York (4), 301-350 